\title{
Subinternship in Radiology - A Practical Start to the Specialization?
}

\section{Famulatur in der Radiologie - der praktische Start ins Fach?}

Authors

Affiliations
R. Kasch ${ }^{1}$, J. Wirkner ${ }^{2}$, N. Hosten ${ }^{3}$, P. Hinz ${ }^{4}$, M. Napp ${ }^{4}$, R. Kessler ${ }^{3}$

Affiliation addresses are listed at the end of the article.
Key words

- medical students

- future career choices

work satisfaction

- subinternship radiology received 26.8.2015

accepted $\quad 7.7 .2016$

\section{Bibliography}

DOI http://dx.doi.org/

10.1055/s-0042-113612

Published online: 22.9.2016

Fortschr Röntgenstr 2016; 188:

1024-1030 @ Georg Thieme

Verlag KG Stuttgart · New York . ISSN 1438-9029

\section{Correspondence \\ Dr. Richard Kasch}

Clinic and Outpatient Clinic for Orthopaedics and Orthopaedic Surgery, University Medicine Greifswald

Sauerbruchstraße

17475 Greifswald

Germany

Tel.: ++ 49/3834/8622494

Fax: ++49/3834/867052

kaschr@uni-greifswald.de

\section{Abstract \\ 7}

Purpose: To identify factors influencing medical students to choose radiology in the fourmonth clinical elective in the final year of medical school following radiology subinternships.

Materials and Methods: A subsample of medical students in a nationwide German online survey evaluated a subinternship in radiology (19 items). They were divided into four groups: Students who could imagine doing a clinical elective in radiology in the practical year based on their experiences during the subinternship ("yes, based on subinternship"), students who could not ("no, based on subinternship") and students who had made this decision prior to the subinternship ("yes, prior to subinternship" and "no, prior to subinternship").

Results: 94 medical students evaluated a radiology subinternship (54.4\% females). Based on their experiences during the subinternship, 54 students (57.4\%) intended to do a final year clinical elective in radiology, 39 of them $(41.5 \%)$ being encouraged by the subinternship. 40 (42.6\%) reported having a negative attitude towards a clinical elective in radiology, 16 of them (17.0\%) having made this decision based on their subinternship experience. Groups did not differ regarding gender $(p=0.396)$ and age $(p=0.853)$. Students motivated to do a final year clinical elective in radiology experienced excellent academic teaching $(\mathrm{p}=0.001)$ and practical involvement ( $p=0.003$ ), achieved their learning goals more often $(p=0.001)$, were better integrated into the team $(\mathrm{p}=0.001)$, and acquired more practical skills $(\mathrm{p}=0.003)$. Overall satisfaction was higher in these groups $(p=0.001)$.
Conclusion: Satisfaction with a radiology subinternship is crucial for motivating medical students to do a final year clinical elective in radiology. A structured subinternship and continuous mentoring should be targeted to keep students connected to radiology.

Key Points:

- Radiology subinternships influence further interest in the specialization.

- The quality and structure of teaching critically influence student satisfaction.

- Team integration and practical involvement positively affect the attitude towards a specialization.

Citation Format:

- Kasch R, Wirkner J, Hosten N et al. Subinternship in Radiology - A Practical Start to the Specialization? Fortschr Röntgenstr 2016; 188: 1024-1030

\section{Zusammenfassung}

Ziel: Ziel ist die Identifikation von Faktoren, die radiologische Famulanten zur Wahl eines radiologischen PJ-Tertials motivieren und somit die Bindung an das Fach stärken.

Material und Methoden: Eine Subgruppe Medizinstudierender aus einer deutschlandweiten Onlineumfrage zu Praktika im Medizinstudium evaluierte eine radiologische Famulatur (19 Variablen). Diese analysierten wir in vier Gruppen: Studierende, die sich aufgrund der Famulaturerfahrungen vorstellen konnten, ein PJ-Wahltertial Radiologie zu absolvieren („Ja, durch Famulatur“), Studierende, die dies verneinten („Nein, durch Famulatur"), und Studierende, die bereits vor der Famulatur festgelegt waren (,Ja, vor Famulatur“ bzw. „Nein, vor Famulatur“).

Ergebnisse: 94 Studierende (54,4\% weiblich) evaluierten eine radiologische Famulatur, von denen 54 (57,4\%) ihr PJ-Wahltertial in der Radiologie ma- 
chen wollten. 39 (41,5\%) wurden durch die Famulatur in dieser Entscheidung bestärkt. 40 (42,6\%) Studierende verneinten den Wunsch nach einem Radiologie-PJ-Tertial, von denen 16 (17,0\%) die Famulatur zum Anlass nahmen. Hinsichtlich Geschlecht $(p=0,396)$ und Alter $(p=0,853)$ unterschieden sich die Gruppen nicht. Neben einer besseren didaktischen $(p=0,001)$ und fachlichen Qualität der Lehre $(\mathrm{p}=0,001)$ profitierten Studierende, die das PJ-Wahltertial Radiologie belegen wollten, von einem stärkeren Praxisbezug $(p=0,003)$, erreichten häufiger ihre Lernziele $(p=0,001)$, wurden besser von den Ärzten betreut $(p=0,001)$ und erwarben mehr praktische Kompetenzen $(p=0,003)$. Die allgemeine Zufriedenheit war in beiden bejahenden Subgruppen höher $(\mathrm{p}=0,001)$.

Schlussfolgerung: Die Zufriedenheit radiologischer Famulanten ist entscheidend für die Motivation, ein PJ-Wahltertial Radiologie zu absolvieren. Eine klare Strukturierung des Praktikums sowie ein Mentorenprogramm sind erstrebenswert, damit Studierende dem Fachgebiet verbunden bleiben.

\section{Introduction}

\section{$\nabla$}

Internships last a total of four months divided into two- to four-week subinternships in the second phase of medical school $\S 7$ paragraph 4 of the Medical Licensure Act [1]). The goal of the subinternship is to make medical students familiar with patient care at inpatient and outpatient medical facilities ( $§ 7$ paragraph 1 Medical Licensure Act [1]).

American studies have shown that practical experience in radiology, particularly early in the curriculum, makes a major contribution to the acquiring of radiological interpretation skills among students, has a positive effect on the perception of radiology among students, and motivates students to subsequently choose to specialize in radiology [2-6].

Thus a subinternship in radiology is very important because it provides medical students with more patient contact as well as more contact with practicing physicians and helps students to apply theoretical knowledge. The elimination of the clinical year in October 2004 further highlights the importance of clinical internships (subinternships and practical year) in the training of medical students. This applies in particular to medical students in reformed conventional courses of study and model courses of study since radiology is increasingly taught as a cross-disciplinary subject in interdisciplinary courses. As a result, it may be more difficult for medical students to perceive radiology as an independent area of specialization depending on the curriculum of the main specialty. According to students, this is a reason for selecting a subinternship in radiology [7].

While courses such as lectures and seminars are evaluated by medical students at German universities on a regular and usually mandatory basis, there is no information regarding student perception of practical training received as part of the most important internships in the curriculum, i.e., subinternship and practical year. In order to develop a comprehensive strategy to motivate medical students to study radiology and subsequently specialize in radiology, it is important to understand student perception of the specialization.

The authors therefore investigated the influence a radiology subinternship has on interest in a clinical elective in radiology in the practical year. Since early positive practical experiences promote further interest in the specialization
$[2,6,8]$, the authors assumed that students with a positive attitude toward a clinical elective in radiology in the practical year were more satisfied with their radiology subinternship than those with a negative attitude $[9,10]$. The results of the present study are intended to help determine how to get students excited about radiology in order to ultimately convince them to specialize in radiology.

\section{Materials and Methods \\ $\nabla$}

In the summer semester 2012, the study group of the German Society of Orthopedic Surgery and Traumatology conducted an online survey with the help of the software EvaSys Education Suite (electricpaper GmbH, Lüneburg, Germany). Medical students in Germany were surveyed regarding their internships (nursing internship, subinternship, and practical year) with the goal of obtaining the first comprehensive evaluation. Students were contacted via the student council and office of student affairs of the individual departments [11]. In total, 9079 medical students participated in the survey. 4146 (45.7\%) students in their first to third year of medical school evaluated an at least fourweek subinternship.

For the subgroup examined in this study, i. e., medical students completing an at least four-week subinternship in radiology, 19 questions regarding the subinternship were analyzed. Sociodemographic characterization and the results of the evaluation of the subinternship in radiology are presented in the following. In particular, the integration in the team, the quality and structure of teaching, the role of teachers, and satisfaction with the internship are to be discussed in greater detail.

The goal of the analyses is to compare decisions for and against a clinical elective in radiology in the practical year made on the basis of subinternship experiences and to determine the reasons for selecting a clinical elective in radiology. For the Likert scales, 1 and 2 were evaluated as "dissatisfied or low approval", 3 as "undecided", and 4 and 5 as "satisfied or high approval". Participants were divided into four groups: Students in the "yes, based on subinternship" group had a positive attitude toward completing a clinical elective in radiology in the practical year based on their subinternship experiences. Students in the "no, based on subinternship" group had a negative attitude toward completing a clinical elective in radiology in the practical year based on their subinternship experiences. These students were analyzed separately from those who had already decided yes before the subinternship ("yes, prior to subinternship" group) or no before the subinternship ("no, prior to subinternship" group).

Statistical evaluation was performed using SPSS 22.0 (IBM corp, Armonk, USA). In addition to descriptive statistics, the $\mathrm{Chi}^{2}$ test was performed for frequencies and univariate ANOVAs were used for the individual variables ( $\bullet$ Table 1 ) with the between-subjects factor group ("yes prior to subinternship" vs. "no, prior to subinternship" vs. "yes, based on subinternship" vs. "no, based on subinternship").

\section{Results}

\section{$\checkmark$}

94 medical students stated that they had completed their subinternship in radiology. $54.4 \%$ of these students were female. Most survey participants were in a relationship 
Table 1 Subgroup analysis of the items regarding integration into the team of doctors, quality and structure of teaching, teachers and satisfaction.

\begin{tabular}{|c|c|c|c|c|c|c|c|c|c|c|}
\hline category & item & $\begin{array}{l}\text { yes, prior to subin- } \\
\text { ternship (mean (SD)) } \\
\mathrm{N}=15\end{array}$ & $\begin{array}{l}\text { yes, based on subin- } \\
\text { ternship (mean (SD)) } \\
N=39\end{array}$ & $\begin{array}{l}\text { no, prior to subin- } \\
\text { ternship (mean (SD)) } \\
\mathrm{N}=\mathbf{2 4}\end{array}$ & $\begin{array}{l}\text { no, based on subin- } \\
\text { ternship (mean (SD)) } \\
\mathrm{N}=16\end{array}$ & $\mathbf{F}$ & p-value & $\begin{array}{l}\text { dissatisfied or } \\
\text { low approval } \\
\text { ( } 1 \text { and } 2 \text { in \%) }\end{array}$ & $\begin{array}{l}\text { undecided } \\
\text { ( } 3 \text { in \%) }\end{array}$ & $\begin{array}{l}\text { satisfied or } \\
\text { high approval } \\
\text { ( } 4 \text { and } 5 \text { in \%) }\end{array}$ \\
\hline \multirow{3}{*}{$\begin{array}{l}\text { Integration } \\
\text { into the team } \\
\text { of doctors }\end{array}$} & $\begin{array}{l}\text { During my subinternship I felt well } \\
\text { integrated into the team of doctors }\end{array}$ & $\begin{array}{l}4.13 \\
(0.99)\end{array}$ & $\begin{array}{l}4.23 \\
(0.96)\end{array}$ & $\begin{array}{l}3.46 \\
(1.18)\end{array}$ & $\begin{array}{l}3.25 \\
(1.29)\end{array}$ & 4.63 & 0.005 & 14.9 & 19.2 & 65.9 \\
\hline & $\begin{array}{l}\text { The working atmosphere in the } \\
\text { department/at the clinic was good }\end{array}$ & $\begin{array}{l}4.47 \\
(0.64)\end{array}$ & $\begin{array}{l}4.33 \\
(0.84)\end{array}$ & $\begin{array}{l}4.08 \\
(0.65)\end{array}$ & $\begin{array}{l}3.62 \\
(0.72)\end{array}$ & 4.38 & 0.006 & 2.1 & 17.0 & 80.9 \\
\hline & $\begin{array}{l}\text { I felt very well supervised by the } \\
\text { doctors }\end{array}$ & $\begin{array}{l}4.13 \\
(0.83)\end{array}$ & $\begin{array}{l}4.44 \\
(0.85)\end{array}$ & $\begin{array}{l}3.75 \\
(0.94)\end{array}$ & $\begin{array}{l}3.13 \\
(1.15)\end{array}$ & 8.28 & 0.001 & 12.7 & 14.9 & 72.4 \\
\hline \multirow{9}{*}{$\begin{array}{l}\text { Quality and } \\
\text { structure of } \\
\text { teaching }\end{array}$} & Acquisition of specialist knowledge & $\begin{array}{l}4.47 \\
(0.74)\end{array}$ & $\begin{array}{l}4.33 \\
(0.84)\end{array}$ & $\begin{array}{l}3.88 \\
(0.61)\end{array}$ & $\begin{array}{l}3.75 \\
(0.68)\end{array}$ & 4.30 & 0.007 & 1.1 & 18.1 & 80.8 \\
\hline & Practical involvement & $\begin{array}{l}4.38 \\
(1.12)\end{array}$ & $\begin{array}{l}4.55 \\
(0.60)\end{array}$ & $\begin{array}{l}4.26 \\
(0.75)\end{array}$ & $\begin{array}{l}3.56 \\
(1.26)\end{array}$ & 4.96 & 0.003 & 5.4 & 8.8 & 85.8 \\
\hline & Achievement of learning goals & $\begin{array}{l}4.08 \\
(1.12)\end{array}$ & $\begin{array}{l}4.03 \\
(0.94)\end{array}$ & $\begin{array}{l}3.43 \\
(0.79)\end{array}$ & $\begin{array}{l}2.63 \\
(1.26)\end{array}$ & 8.60 & 0.001 & 13.9 & 28.0 & 58.1 \\
\hline & Didactic quality of teaching & $\begin{array}{l}4.08 \\
(1.26)\end{array}$ & $\begin{array}{l}3.95 \\
(0.90)\end{array}$ & $\begin{array}{l}3.26 \\
(0.75)\end{array}$ & $\begin{array}{l}2.69 \\
(1.14)\end{array}$ & 8.32 & 0.001 & 15.2 & 29.3 & 55.5 \\
\hline & Professional quality of teaching & $\begin{array}{l}4.46 \\
(1.13)\end{array}$ & $\begin{array}{l}4.37 \\
(0.79)\end{array}$ & $\begin{array}{l}3.83 \\
(0.72)\end{array}$ & $\begin{array}{l}3.19 \\
(1.05)\end{array}$ & 8.31 & 0.001 & 7.6 & 15.2 & 77.2 \\
\hline & $\begin{array}{l}\text { The structural organization of the } \\
\text { subinternship was good in the } \\
\text { department/clinic }\end{array}$ & $\begin{array}{l}3.57 \\
(1.09)\end{array}$ & $\begin{array}{l}3.84 \\
(1.38)\end{array}$ & $\begin{array}{l}2.96 \\
(1.26)\end{array}$ & $\begin{array}{l}2.38 \\
(1.09)\end{array}$ & 5.88 & 0.001 & 28.0 & 23.6 & 48.4 \\
\hline & The mentoring program was good & $\begin{array}{l}3.50 \\
(1.34)\end{array}$ & $\begin{array}{l}3.57 \\
(1.12)\end{array}$ & $\begin{array}{l}2.74 \\
(0.75)\end{array}$ & $\begin{array}{l}2.50 \\
(1.41)\end{array}$ & 4.86 & 0.004 & 23.0 & 40.7 & 36.3 \\
\hline & $\begin{array}{l}\text { I had to perform too many non- } \\
\text { patient-oriented tasks }\end{array}$ & $\begin{array}{l}2.14 \\
(1.23)\end{array}$ & $\begin{array}{l}1.68 \\
(0.85)\end{array}$ & $\begin{array}{l}1.83 \\
(0.89)\end{array}$ & $\begin{array}{l}2.63 \\
(1.36)\end{array}$ & 3.45 & 0.020 & 72.3 & 21.3 & 6.4 \\
\hline & Bedside teaching was performed. & $\begin{array}{l}2.00 \\
(1.18)\end{array}$ & $\begin{array}{l}2.35 \\
(1.55)\end{array}$ & $\begin{array}{l}1.87 \\
(1.18)\end{array}$ & $\begin{array}{l}1.50 \\
(0.89)\end{array}$ & 1.74 & 0.165 & 69.1 & 16.0 & 14.9 \\
\hline \multirow[t]{5}{*}{ Teachers } & $\begin{array}{l}\text { I learned the most from the assistant } \\
\text { doctors or ward doctors }\end{array}$ & $\begin{array}{l}3.93 \\
(0.80)\end{array}$ & $\begin{array}{l}3.92 \\
(1.24)\end{array}$ & $\begin{array}{l}3.35 \\
(1.43)\end{array}$ & $\begin{array}{l}3.87 \\
(1.30)\end{array}$ & 1.19 & 0.318 & 14.9 & 20.2 & 64.9 \\
\hline & $\begin{array}{l}\text { l learned the most from the specia- } \\
\text { list doctors }\end{array}$ & $\begin{array}{l}3.67 \\
(1.11)\end{array}$ & $\begin{array}{l}3.51 \\
(1.10)\end{array}$ & $\begin{array}{l}3.17 \\
(0.98)\end{array}$ & $\begin{array}{l}2.47 \\
(1.25)\end{array}$ & 4.02 & 0.010 & 24.5 & 33.0 & 42.5 \\
\hline & $\begin{array}{l}\text { l learned the most from the senior } \\
\text { doctors }\end{array}$ & $\begin{array}{l}3.60 \\
(1.40)\end{array}$ & $\begin{array}{l}3.21 \\
(1.32)\end{array}$ & $\begin{array}{l}3.13 \\
(1.06)\end{array}$ & $\begin{array}{l}2.33 \\
(0.98)\end{array}$ & 2.89 & 0.041 & 30.1 & 32.3 & 37.6 \\
\hline & $\begin{array}{l}\text { I learned the most from the head } \\
\text { doctor }\end{array}$ & $\begin{array}{l}2.27 \\
(1.22)\end{array}$ & $\begin{array}{l}2.54 \\
(1.60)\end{array}$ & $\begin{array}{l}2.00 \\
(1.04)\end{array}$ & $\begin{array}{l}1.93 \\
(1.22)\end{array}$ & 1.11 & 0.350 & 61.3 & 20.4 & 18.3 \\
\hline & $\begin{array}{l}\text { Contact to the teachers was close } \\
\text { and always possible }\end{array}$ & $\begin{array}{l}3.93 \\
(1.28)\end{array}$ & $\begin{array}{l}3.95 \\
(1.39)\end{array}$ & $\begin{array}{l}3.96 \\
(0.88)\end{array}$ & $\begin{array}{l}2.47 \\
(1.41)\end{array}$ & 5.71 & 0.001 & 21.3 & 17.0 & 61.7 \\
\hline \multirow[t]{2}{*}{ Satisfaction } & My overall impression is positive & $\begin{array}{l}4.47 \\
(0.92)\end{array}$ & $\begin{array}{l}4.69 \\
(0.47)\end{array}$ & $\begin{array}{l}3.96 \\
(0.81)\end{array}$ & $\begin{array}{l}3.38 \\
(1.02)\end{array}$ & 13.37 & 0.001 & 5.4 & 13.8 & 80.8 \\
\hline & I am satisfied with my subinternship & $\begin{array}{l}4.40 \\
(0.91)\end{array}$ & $\begin{array}{l}4.49 \\
(0.76)\end{array}$ & $\begin{array}{l}3.96 \\
(0.81)\end{array}$ & $\begin{array}{l}3.00 \\
(1.15)\end{array}$ & 11.87 & 0.001 & 8.5 & 18.1 & 73.4 \\
\hline
\end{tabular}

(0.91) (0.76) (1.15)

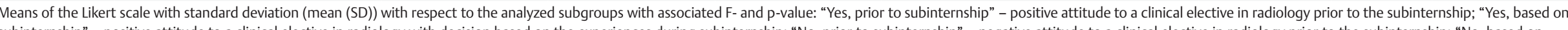

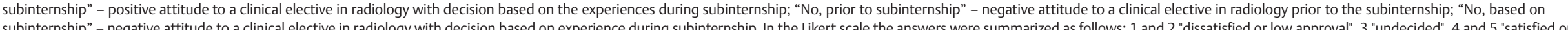

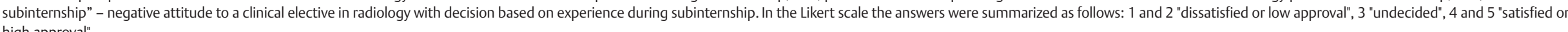
high approval". 
( $59.8 \%$ with $2.3 \%$ being married) or were single $(39.1 \%)$. $1.1 \%$ were divorced and no one was widowed. The age analysis showed that the majority of participants (61.7\%) were between the ages of 25 and 27 at the time of the survey. The 94 students were enrolled at one of 30 of the 36 medical schools in Germany.

\section{Subgroup analysis}

In total, 54 (57.4\%) medical students completing a subinternship in radiology had a positive attitude toward a clinical elective in radiology in the practical year. 39 (41.5\%) of these students were encouraged by the subinternship ("yes, based on subinternship") and 15 (16\%) had already made this decision before the subinternship ("yes, prior to subinternship"). 40 (42.6\%) students had a negative attitude toward a clinical elective in radiology in the practical year, with $16(17.0 \%)$ coming to this conclusion as a result of the subinternship ("no, based on subinternship"). The majority of those not wishing to complete a clinical elective in radiology $(24(25.5 \%))$ had already come to this decision before the subinternship ("no, prior to subinternship"). With respect to gender and age, there was no significant difference between the groups (gender: $\mathrm{Chi}^{2}=2.97, \mathrm{p}=0.396$; age: $\mathrm{F}<1, \mathrm{p}=0.853$ ).

When comparing the four groups, the "yes, based on subinternship" group had the highest scores for all variables regarding integration in the team while the "no, based on subinternship" group had the lowest scores for these variables. In the category "quality and structure of teaching", the "no, based on subinternship" group rated the achievement of learning goals, didactic quality of teaching, professional quality of teaching, and structural organization of the subinternship highly significantly poorer $(p=0.001$; - Fig. 1). In the "no, based on subinternship" group, contact to teachers was also significantly poorer ( $p=0.001$; $\bullet$ Fig. 1 ). Also when comparing the variables in the "satisfaction" category, the "yes, based on subinternship" group had the highest scores while the "no, based on subinternship" group had the lowest.

\section{Integration in the team}

The students with a positive attitude toward a clinical elective in radiology after the subinternship rated the variables in the "integration into the team of doctors" category significantly better than those with a negative attitude toward a clinical elective in radiology $(\mathrm{p}<0.01$; $~$ Table 1$)$. In total, $65.9 \%$ of survey participants stated that they felt well or very well integrated in the team of doctors. $80.9 \%$ of participants felt that the working atmosphere was good or very good. $72.4 \%$ felt well supervised by the doctors.

\section{Quality and structure of teaching}

A large majority of students felt that the conveyance of specialist knowledge was good or very good (80.8\%). The acquisition of specialist knowledge was rated significantly higher in both groups with a positive attitude toward a clinical elective in radiology $(\mathrm{p}=0.007) .85 .8 \%$ of medical students rated practical involvement during their subinternship as good or very good and $77.2 \%$ were satisfied with the professional quality of teaching. Approximately every second survey participant was satisfied with the didactic quality. $58.1 \%$ felt they achieved their learning goals. The univariate analyses regarding the quality of teaching were statistically significant in all subgroups. However, both groups with a positive attitude toward a clinical elective in radiology indicated greater satisfaction ( $\bullet$ Table 1 ).

The structural organization of the subinternship was described as good or very good by every second survey participant. The presence/quality of a mentoring program (continuous supervision by a dedicated contact person for the duration of the subinternship) had a positive effect on only one-third of students. $6.4 \%$ felt that they were assigned too many non-patient-oriented tasks. Only $15 \%$ felt that sufficient bedside teaching was performed during the subinternship. According to students, there was significantly more bedside teaching in the positively evaluated subinternships. Medical students who wanted to subsequently complete a clinical elective in radiology rated the structural organization of the subinternship, the mentoring program, and bedside teaching better ( $\bullet$ Table 1 ).

\section{Teachers}

Two-thirds of survey participants indicated that the contact to teachers was close and always possible, with the students in the "no, based on subinternship" group seeming to have had comparatively less contact ( $\bullet$ Table 1 ). Moreover, teaching was primarily performed by assistant doctors. The groups differed significantly with respect to learning from specialists and senior doctors, with those still interested in radiology having learned more from these two doctor groups. Head doctors did an average amount of teaching.

\section{Satisfaction}

$73.4 \%$ of survey participants were (very) satisfied with their radiology subinternship, with the satisfaction of the students with a positive attitude toward a clinical elective in radiology in the practical year being significantly higher $(\mathrm{p}=0.001)$. The groups also differed significantly with regard to their overall impression $(p=0.001)$, with the overall impression of $80.8 \%$ of participants being positive (॰ Table 1).

\section{Discussion}

The current study examined the extent to which a subinternship in radiology is suitable for promoting further interest in the specialization. For this purpose, the authors conducted subgroup analysis of a Germany-wide online survey of the study group of the German Society of Orthopedic Surgery and Traumatology evaluating students completing an at least four-week subinternship in radiology. The present results show that integration in the team of doctors and the quality and structure of teaching in the subinternship have a particular effect on interest in radiology.

To our knowledge, the influence of radiology subinternships on student perception of the specialization as well as on student motivation to select a clinical elective in radiology in the practical year has not yet been determined and published in Germany. However, Osenberg et al. [12] conducted a large online survey regarding career planning of medical students in all semester at all German medical schools and evaluated 4037 questionnaires, including 562 participants completing their practical year at the time of the survey. $6.6 \%$ of partici- 


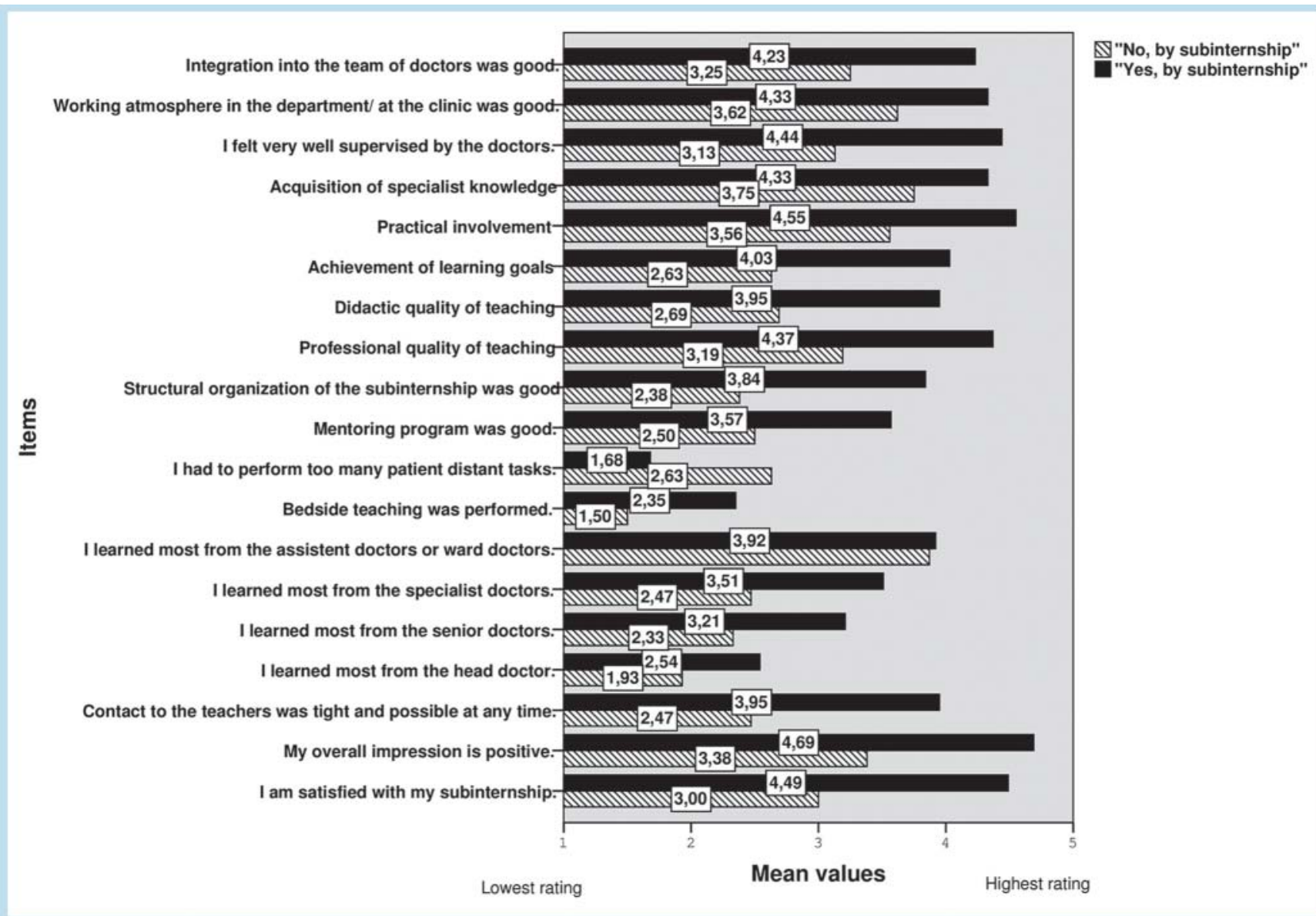

Fig. 1 Comparison of the mean values of the Likert scale of the "no, based on subinternship" and "yes, based on subinternship" groups.

pants specified radiology as their targeted area of specialization. However, a negative trend was seen in the comparison of students in the first semester with students completing their practical year: The percentage of students with radiology as their desired area of specialization decreased by $24 \%$ over the course of their studies. The reasons for this negative trend were not further examined. While courses such as lectures and seminars are evaluated on a regular and often mandatory basis, there is no standardized form of quality control of teaching in subinternships. There are many reasons for this: Subinternships in radiology can be completed in radiology practices or medical centers as well as in radiology departments or institutes at hospitals with large differences in structure, organization, and patient groups.

In particular in light of the academic reform resulting in increasingly more German universities offering a reformed conventional course of study or model course of study, increasing importance must be placed on radiology teaching during subinternships. Reformed conventional and model courses of study are characterized by the elimination of the strict separation between the preclinical and the clinical phase. Focus is being placed on integrative, organ-centered teaching in learning blocks or modules $[7,13]$. For radiology as a cross-disciplinary subject, there is a risk of specialist content being increasingly taught in interdisciplinary courses. The perception of radiology as an independent area of specialization could decline depending on the curriculum of the main specialties. Students who select radiology for a subinternship and thus show fundamental interest in this specialization should be supported accordingly in order to maintain and increase interest in radiology and to ultimately convince students in their practical year to specialize in radiology.

Catalogs of learning goals and logbooks can help students and teachers to maintain an overview in the clinical routine and to achieve learning goals [14]. Moreover, the introduction of a logbook can improve integration of students in the team of doctors [15]. Therefore, definition of a standard curriculum as an education guideline for radiology subinternships in the form of a logbook seems useful. Despite the lack of a standardized duration of subinternships in Germany (minimum duration between 14 days and 4 weeks depending on the state), such a logbook could facilitate the structured teaching of competences. At the same time, teachers would be able to monitor didactic and structural quality, while students could monitor learning progress [14]. Content-related and structural recommendations in this regard are provided in the white paper of the European Society of Radiology (ESR) regarding the status of radiology education in Europe [9].

On the whole, students were satisfied with an at least fourweek radiology subinternship according to our survey. Therefore, $80.8 \%$ of students indicated having a positive overall impression of the subinternship and almost $75 \%$ of students were (very) satisfied with their subinternship. It is noteworthy that the evaluation of the medical students who selected radiology for their clinical elective based on the subintern- 
ship often differed only minimally from the evaluation of those who had decided to complete a clinical elective in radiology already prior to the subinternship. The reverse is not true. Students who were "lost" as a result of the subinternship were often significantly less satisfied than those who already had a negative attitude toward a clinical elective in radiology prior to the subinternship. Radiology subinternships can have a positive influence on approx. $41.5 \%$ of students, but approx. $17.0 \%$ are not reached. In total, approx. $58.5 \%$ can be influenced by the subinternship, while $41.5 \%$ have already made their decision before the subinternship. Although only almost $60 \%$ of students decide for or against radiology as their clinical elective in the practical year based on the radiology subinternship, the effectiveness of the subinternship as a decision aid can be considered high. Therefore, for example, only $30 \%$ of students completing a clinical elective in general medicine in the practical year were influenced with respect to their decision to receive further training in this specialization [16].

The structural conditions of the subinternship were a decisive factor in the subsequent selection of radiology in the practical year. Students with the desire to select radiology as their clinical elective in the practical year felt that the structural organization of their subinternship was significantly better, with the availability of dedicated contact partners (mentoring program) in particular playing a decisive role. Even if only onethird of students were satisfied with the mentoring program, we found a highly significant difference between the "yes, based on subinternship" group and the "no, based on subinternship" group. This emphasizes the importance of the presence of a dedicated contact person in the form of a mentor. A structured focus group analysis of expectations and experiences of students in their practical year in internal medicine showed that the presence of a dedicated medical contact person for the duration of the internship is particularly important to students [17]. The impact of a mentor from the selected area of specialization on a student's decision in favor of the specialty has already been shown multiple times in general medicine [17 - 19].

The organization and structure of teaching in the subinternship also had a strong influence on interest in radiology in the practical year. The didactic and professional quality of teaching was evaluated significantly better by students with a positive attitude toward a clinical elective in radiology, with the subjective sense of achieving learning goals, good practical involvement, and bedside teaching having a decisive influence. Comparable results are seen in the evaluations of other subinternships, e.g. orthopedics and trauma surgery [20]. These results should be used to improve the teaching qualifications and motivation of teaching doctors with targeted didactic training.

In particular, the importance of patient contact for motivating students to select radiology was already emphasized by Fielding et al. [21]. The study group also emphasizes that the outdated view of radiologists as simple diagnosticians without therapeutic competences represents a significant obstacle to the selection of radiology as a specialization. Therefore, it seems very important to provide direct patient contact and bedside teaching during radiology subinternships and to strengthen teaching in the area of interventional radiology to emphasize the therapeutic competences of radiologists. Students should be made aware of the spe- cial role of radiology with respect to communication - an increasingly important core competence of the radiologist: Radiology allows close interdisciplinary collaboration with other areas of specialization, both in diagnostic radiology, e.g. in clinical conferences such as tumor conferences, and in interventional radiology. Future doctors can benefit here from a particularly varied and interesting interdisciplinary field of work.

Furthermore, our data show that teaching responsibilities in subinternships are largely assumed by assistant doctors and to a lesser degree by specialists, senior doctors, and head doctors. Dutch study groups were able to show the same for different clinical internships [22 - 24]. Even if assistants did most of the teaching, teaching by specialists and senior doctors, with a tendency toward significance in the case of head doctors, seems to be a decisive factor for the subsequent professional motivation of students completing a radiology subinternship. There is significant potential to improve or restructure teaching to provide greater incorporation of specialists in practical training. Improved contact between students and head doctors can be beneficial for both sides not only with respect to the teaching of specialist knowledge but also in particular with respect to career planning for students interested in radiology and a scientific career in the specialization. Regular casual meetings, e.g. dinners with the head doctor, as already practiced in the curriculum in the United States and England, could provide new motivation here [25].

Moreover, the integration in the team of doctors proved to be a further decisive factor in motivating students completing a subinternship in radiology to select a clinical elective in radiology in the practical year with both the integration in the team of doctors and the working atmosphere at the hospital being important. These results also coincide with the findings of other German study groups who used structured focus group analysis to examine the expectations and experiences of students in internal medicine during ward internships and the practical year $[17,26]$.

A limitation is that the present survey as a self-selected sample does not allow conclusions about the population of all medical students completing a radiology subinternship [27]. At the same time the main structural features of the surveyed group correspond with the population (age, gender) of German medical students in the clinical phase. The sociodemographic data are comparable with that of other large Germany-wide surveys $[12,27]$. Thus, in the absence of further studies, the authors assume that the results of this analysis are representative of the typical views of medical students completing a subinternship in radiology [12]. The sample of 94 medical students who completed an at least four-week radiology subinternship is only mediumsized. This is a significant limitation in particular for additional subgroup analyses (e.g. according to age or gender). The limiting factor here is that radiology is one of the smaller disciplines and therefore significantly larger samples are barely possible. Moreover, the selection of medical students completing an at least four-week radiology subinternship suggests a survey bias. Therefore, it is possible that primarily students who already had above-average interest in radiology compared to those completing a radiology subinternship lasting less than four weeks were surveyed. Another limitation is that the use of the term "bedside teaching" in 
connection with radiology is not as common as in other (inpatient) specializations. It therefore cannot be ruled out that the question regarding bedside teaching in the category "quality and structure of teaching" was misunderstood and thus answered incorrectly.

\section{Conclusion}

$\nabla$

The satisfaction of medical students with their radiology subinternship is of great importance for subsequent choices, in particular motivation to select radiology for their clinical elective in the practical year. Closer contact with students is desirable not only with respect to the teaching of specialist knowledge but also with respect to targeted early encouragement of students with a special interest in radiology. Practical involvement and bedside teaching are particularly important to students. A comprehensive representation of radiology including diagnostics, treatment, and interdisciplinarity should be provided.

\section{Clinical relevance of the study}

Radiology subinternships are important for the further interest of students in the specialization.

- The quality and structure of teaching in subinternships are decisive for student satisfaction.

- Integration in the team of doctors and practical involvement positively affect subjective learning success.

\section{Affiliations}

1 Center for Orthopedics Trauma Surgery and Rehabilitation Medicine, Clinic and Outpatient Clinic for Orthopedics and Orthopedic Surgery, University Medicine Greifswald, Germany

Department of Biological and Clinical Psychology, Institute of Psychology, Internal Medicine A, University Medicine Greifswald, Germany

Institute of Diagnostic Radiology and Neuroradiology, University Medicine Greifswald, Germany

${ }^{4}$ Center for Orthopedics Trauma Surgery and Rehabilitation Medicine, Clinic of Trauma and Orthopaedic Surgery, University Medicine Greifswald, Germany

\section{Acknowledgements

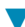

The authors would like to thank the German Society for Orthopaedics and Trauma Surgery (DGOU) for giving the opportunity to do the survey in providing a grand of $10000 €$ for this study. The study sponsor the DGOU, had no influence on the study design, conduct, interpretation or report, or in the decision to submit the article for publication.

\section{References}

1 Approbationsordnung für Ärzte vom 27. Juni 2002 (BGBl. I S. 2405), die zuletzt durch Artikel 2 der Verordnung vom 2. August 2013 (BGBl. I S. 3005) geändert worden ist; 2013, http://www.gesetze-im-internet. de/bundesrecht/_appro_2002/gesamt.pdf

2 Branstetter BF 4th, Faix LE, Humphrey AL et al. Preclinical medical student training in radiology: the effect of early exposure. Am J Roentgenol 2007; 188: W9-W14

3 Branstetter BF 4th, Humphrey AL, Schumann JB. The long-term impact of preclinical education on medical students' opinions about radiology. Academic Radiology 2008; 15: 1331 -1339
4 Chen MY, Ott DJ, Richards B. Impact and value of junior rotation in radiology. Investigative Radiology 1990; 25: 1153 - 1155

5 Relyea-Chew A, Chew FS. Dedicated core clerkship in radiology for medical students development, implementation, evaluation, and comparison with distributed clerkship. Academic Radiology 2007; 14: $1127-1136$

6 Kourdioukova EV, Verstraete $K L$, Valcke $M$. Radiological clerkships as a critical curriculum component in radiology education. European Journal of Radiology 2011; 78: 342 - 348

7 Dettmer S, Weidemann J, Fischer $V$ et al. Integrative teaching in radiology - a survey. Fortschr Röntgenstr 2015; 187: 260-268

8 Shepherd SM, Dudewicz DM, Hindo WA. Immediate and long-term effects of a sophomore radiology elective. Academic Radiology 2003; 10: $786-793$

9 European Society of Radiology. Undergraduate education in radiology. A white paper by the European Society of Radiology. Insights Imaging $2011 ; 2: 363-374$

10 Dettmer S, Kuhlmey A. Studienzufriedenheit und berufliche Zukunftsplanung von Medizinstudierenden - ein Vergleich zweier Ausbildungskonzepte. In: Schwartz FW, Angerer P (eds.). Arbeitsbedingungen und Befinden von Ärztinnen und Ärzten. Befunde und Interventionen. Köln: Deutscher Ärzte Verlag; 2010: 103-115

11 Kasch $R$, Engelhardt $M$, Förch $M$ et al. Ärztemangel: Was tun, bevor Generation Y ausbleibt? Ergebnisse einer bundesweiten Befragung. Zentralbl Chir 2016; 141: 190-196. DOI: 10.1055/s-0035-1557857. Epub 2015 Sep 21.

12 Osenberg $D$, Huenges $B$, Klock $M$ et al. Wer wird denn noch Chirurg? Zukunftspläne der Nachwuchsmediziner an deutschen Universitäten. Chirurg 2010; 6: 308-315

13 Hibbeler B. Modellstudiengänge: Bausteine für ein gutes Studium. Dtsch Arztebl International 2014; 10: 7-8

14 Froehlich $S$, Obertacke $U$, Ruesseler $M$ et al. Lehrzielkatalog im Pflichtund Wahlbereich des Praktischen Jahres für die Inhalte des Faches „Orthopädie und Unfallchirurgie“. Z Orthop Unfall 2011; 149: 568-574

15 Kraus B, Jünger J, Schrauth $M$ et al. Logbücher im klinisch-praktischen Einsatz: Profitieren die Studenten? Eine Bestandsaufnahme bei PJ-Studenten der Inneren Medizin. GMS Zeitschrift Für Medizinische Ausbildung 2007; 24: Doc 112

16 Abendroth J, Schnell U, Lichte $T$ et al. Motive für die Fachgebietswahl ehemaliger PJ-Studierender im Fach Allgemeinmedizin: Ergebnisse einer Querschnittsbefragung der Jahrgänge 2007-2012. GMS Zeitschrift Für Medizinische Ausbildung 2014; 31: Doc11

17 Schrauth $M$, Weyrich $P$, Kraus B et al. Lernen am späteren Arbeitsplatz: Eine Analyse studentischer Erwartungen und Erfahrungen im „Praktischen Jahr“. Z Evid Fortbild Qual Gesundhwes 2009; 103: 169-174

18 Buddeberg-Fischer B, Klaghofer R, Stamm M. Family physicians in Switzerland: transition from residency to family practice. Fam Med 2011; 43: $29-36$

19 Henderson E, Berlin A, Fuller J. Attitude of medical students towards general practice and general practitioners. Br J Gen Pract 2002; 52: 359-363

20 Kasch R, Wirkner J, Meder A et al. Wer bleibt nach einer Famulatur in O\&U dem Fachbereich treu? Ergebnisse einer bundesweiten Umfrage. Z Orthop Unfall 2016, im Druck

21 Fielding JR, Major NM, Mullan BF et al. Choosing a specialty in medicine: female medical students and radiology. American Journal of Roentgenology 2007; 188: 897 -900

22 Remmen R, Denekens J, Scherpbier A. Evaluation of skills training during clerkships using student focus groups. Med Teach 1998; 20: 428-432

23 Van Der Hem-Stokroos HH, Scherpbier AJJA, Van Der Vleuten CPM et al. How effective is a clerkship as a learning environment? Med Teach 2001; 23: 599-604

24 Busari JO, Scherpbier AJJA. Residents' perception of their role in teaching undergraduate students in the clinical setting. Med Teach 2009; 22: $348-353$

25 Educational curriculum of the Department of Radiology of McMaster University; 2016, Abrufbar unter: http://www.fhs.mcmaster.ca/radiology/residency/curriculum.html Abgerufen am 28.04.2016

26 Köhl-Hackert N, Krautter M, Andreesen S et al. Lernen am späteren Arbeitsplatz: eine Analyse studentischer Erwartungen an den Stationseinsatz im Fachbereich der Inneren Medizin. GMS Zeitschrift Für Medizinische Ausbildung 2014; 31: Doc43

27 Gibis B, Heinz A, Jacob R et al. The career expectations of medical students: findings of a nationwide survey in Germany. Dtsch Arztebl Int 2012; 109: $327-332$ 